\title{
The Importance of Multimedia and Interactive Content for Increasing Tourist Attractiveness of the Territory
}

\author{
Ekaterina Vladimirovna Vishnevskaya \\ Tatiana Bronislavovna Klimova \\ Irina Victorovna Bogomazova \\ Elena Vladimirovna Dumacheva \\ Oksana Vladimirovna Yakovenko
}

Belgorod State University, Russia, 308015, Belgorod, Pobedy str., 85

Doi:10.5901/mjss.2015.v6n4s1p561

\begin{abstract}
The main trend of tourism development is the development of applications for mobile phones, $20 \%$ of them is applications in the field of tourism. A relatively new trend in the market applications for travelers are audio guides - convenient option for independent exploring the city attractions. Existing on the market mobile applications have flaws. But compared with their traditional rivals mobile audio guides have several advantages. Unlike paper guidebooks you can listen audio guides and seeing the sights with pleasure, with full freedom of movement. The Russian market of mobile audio guides are not very saturated. But the main trend that is the people are more interested in a quality product. Belgorod Literary Museum first began providing audio tours using mobile applications in the Belgorod region. Many citizens and guests celebrate the historic attraction of Belgorod thanks to the project «Open air museum». Mobile applications are a tool for tourism development and investment attraction.
\end{abstract}

Keywords: mobile applications, audio guide, interactive content, tourist potential of the region.

\section{Introduction}

Tendencies of development of tourist and hotel branches specify that for ensuring competitiveness the companies need to use actively new technologies in work with clients. It is about a wide set of functions which has to be provided both the «usual» internet-sites, and the sites optimized for mobile devices and mobile applications. Treat such functions: online reservation, tracking of flights, electronic commerce, responses of users and so on.

Mobile applications became one of the main trends in development of information technologies. If in 2008, in a year of start of App Stores, the market of mobile applications was only formed, by the present time the market entered a phase of active growth.

Applications market is divided into the following segments:

- Content-based applications,

- Business applications,

- Mobile games,

- Mobile social networks.

According to research by experts of the tourism market for 2013, the number of independent online booking services for travelers in comparison with 2013 has increased almost 1.5 times. Ease of finding and paying the various stages of a trip online greatly increases the number of travelers who want to plan their holidays. Note that travelers are not only self-booking of tickets, hotels, vehicles on the Internet, but also to develop new areas and tools that can make the journey more comfortable and interesting. According to experts, the main trend of development of tourism are applications for mobile phones.

The aim of the article is to study the role of introducing multimedia and interactive content to enhance the tourist attractiveness of the territory. 


\section{Method}

Audio guides are widely distributed abroad, more and more they appear in Russia. They are created as a museum and independent developers. Services audioguide provide some mobile network operators. In Russia, audio guides can be found in museums such as the Hermitage, the Tretyakovskaya Gallery, the State Museum of Fine Arts named after A.S. Pushkin. For the museum audio guides are one of the services for visitors and is usually provided for a fee. Independent developers distribute audio guides as a fee (in the form of discs or paid services of Internet sites) and on the free [5].

Mobile application development in our country are engaged in the company's e-Legion, Hint Solutions, InfoShell, RedMadRobot, Unreal Mojo, ID Company, iD East, MobileUp, DevPocket and «Business Mobile Media».

In 2015 Ruward combined data on nine popular ranking mobile-segment of Russia, and on the basis of these data, the identity was formed-term rating, the first place in which took the company REDMADROBOT, the second and the third place received e-Legion and Unreal Mojo [18].

It should be noted that a significant number of companies engaged in time-processing applications in order to have a full English version of the site and often specify it «by default».

Programs, games, and other applications are distributed through shops developers Apple App Store, Google Play, Windows Phone Store, BlackBerry App World. According to market researchers applications for smartphones, the main directions in which the work programmers are now receiving applications for e-mail, listening to music, watching videos and films for viewing and downloading photos, reading e-books and has called all sorts of applications for office work [3]. According J'son \& Partners Consulting, the main Russian market driver mobile application development are the following.

1. The growth of the mobile consumer. In general, increasing the consumption of mobile services a population of Russia, smartphone sales are growing, growing consumption of mobile traffic, grow sales tablets. This growth is fundamental to the growth of the mobile market development [15].

2. The growth of mobile advertising. Mobile advertising market is linked to the development of the mobile market itself, and these markets are growing rapidly comparable, being adjacent. The growth of mobile advertising budgets is consistent and logical, depending on the growth in the number of mobile applications and their competition for the user [9].

3. Stimulation of the market by the owners of platforms. Google, Apple, Microsoft stimulate development of local markets through competitions, creating more favorable conditions for cooperation. The purpose of the owners of platforms is the maximum number. Applications for its platform getting more competitive service to the user. It spends more on budgets, but in the long term it will have fruit. According to experts J'son \& Partenrs Consulting, a new operating system that runs the Samsung, will aggressively enough to attract developers [8].

4. Relatively high development budgets. Mobile market development is a trend among other developing markets, as the budget for the development of mobile applications remain quite high, more than the cost of development sites. Although, according to many experts, the prices for the development of applications decrease significantly in the next two years [19].

Among the few barriers to market growth of mobile applications experts Json \& Partners Consulting contributed only two points.

1. Lack of awareness of users. Owners of smartphones, especially their age audience, do not enjoy most useful features of the phone, and use it as a normal cell phone for calls and SMS.

2. Difficulties of payment. Difficulty paying for many users in emerging markets remains a major obstacle to the growth of the market, people do not fully trust the mobile systems and do not want to leave evidence of their payment instruments in the system.

Even today in the App Store or Google Play you can find hundreds of applications that can assist in booking a trip or finding housing, orient the map in an unfamiliar city or suggest the most popular restaurants and cafes. [6].

For 2014 in the world downloaded more than 100 billion applications, 20\% of them are applications in the field of tourism. The main clients of mobile applications:

- Travel-management, promotion of domestic tourism (guides, interactive guides, navigation applications, presentation of the region).

- Investment projects.

- Promo - Annex (tourist exhibitions, Promo-presentation of tourist services).

By estimates of the analytical center Distimo, the size of the market of mobile applications makes $\$ 1,5$ billion today, for 2013 he grew by $125 \%$, by 2016 can reach $\$ 7,1$ billion. In Russia the most part of the market belongs to mobile applications for Iphone and Ipad. Google Play applications make about a third of the market [13].

According to research of the company, $67 \%$ of all population of the country are more senior than 12 years connect Network from desktops. Thus only $74 \%$ investigated are active Internet users, and $50 \%$ use the mobile Internet (figure 1). 
The last indicator grew more than twice since 2011 (including use of smartphones (to $39 \%$ of the population), tablets (25\%), Smart TV (10\%), consoles (4\%) and ordinary phones (10\%)).

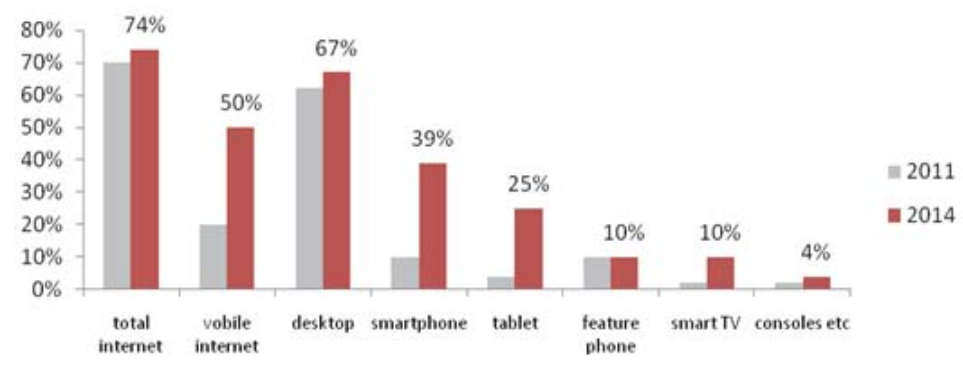

Figure 1. Distribution of users by options of Internet connection

(Adjusting research, Russia, December, 2011 and December, 2014 of 12 years is also more senior than TNS Web Index, $\%$ of the population)

$81 \%$ of users of desktop computers connect from them Network daily, other $19 \%$ - are more rare than once a day, but at least once in a month. The audience of the mobile Internet is more active $-83 \%$ involved every day. The tablet is used by $60 \%$ of people.
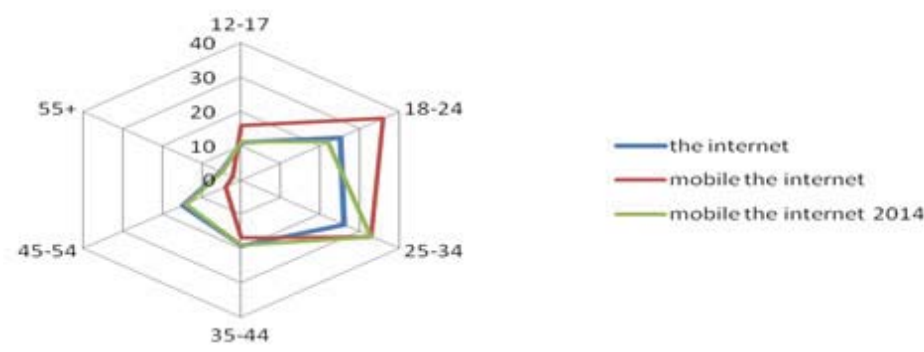

Figure 2. Age structure of Internet users in Russia (adjusting research, Russia, August, 2009, November, 2011 and December, 2014 of 12 years is also more senior than TNS Web In-dex, \% of the population)

Gender ranging in a mobile segment of a network aspires to structure of «the big Internet», though is shifted towards young users (figure 2) so far. In 2009 the same happened with all on - line audience, i.e. for the last five years all Internet increased a share of users among the senior age groups. The general penetration of the Internet in 2017 will make about $77 \%$ [4].

The number of paid loadings continuously grows. And mobile advertizing will become a new push for an exit of tourist branch from crisis. In the 1st quarter of 2014 the market of travel came to the third place on mobile cliques and together with the market of a retail, automobile business and personals received $70 \%$ of the general time on the mobile Internet.

In a release of $34 \%$ of free time travelers prefer to use a smartphones, but not other gadgets (laptops, music players, navigators, and other devices).

In research of the Google company it is told about growth of popularity of mobile search of 2014 in comparison with 2013. This year $24 \%$ of respondents of TopTripTip used mobile search engines for planning of the travel while in 2013 this indicator was equal $18 \%$ [2].

The great popularity is received today by local guides - over certain countries or the cities.

Noticeable trend - Applications "advisers", containing the information on all the surrounding objects traveler, whether parks, restaurants and bus stops. The creators of the famous application Foursquare basic service do exactly recommendations - you can read reviews from people all that is around, add an opinion, share photos, evaluate the 
cuisine - just leave your mark on the history of virtual liked the place.

A relatively new trend in the market applications for travelers are audio guides for smartphones - a convenient option for independent exploring the city attractions.

Compared with their traditional competitors audio guides for smart phones have a number of advantages. Unlike paper guidebooks you can listen audioguide with pleasure and seeing the sights, and not turning the pages guidebook to read the description of the object. Such application gives complete freedom of movement [10].

Moreover, in many cities is hard to find-guides, good speaks English or Russian. At the same time, mobile audio guides is a fascinating story of the author, usually in several languages. Last important factor when choosing a method of exploring the city is the price.

The cost of the excursion in the mobile audio guide starts from 0.99 USD. But a good organized guide or individual trip will cost not less than $\$ 20$.

Despite the tourist information and computerization of processes, and the establishment in recent years of mobile applications as guides for travelers who need to note the weak saturation of the market. Obviously, in the face of competition arises quality product that meets the highest demands of the modern traveler [14].

Consider the market for mobile applications in the area of excursion tourism. For tourism, the following applications: translators, hotel reservations (Hotellook, Booking), ticketing (Aviasales, Scyscanner), guidebooks (TravelMe), Search for travel (BlaBlaCar), car rentals (Sixt), maps.

\section{Results}

After reviewing the applications that exist on the market, we have found some flaws in them. The main ones are:

1. Navigational apps has little information about attractions.

2. Bad navigation.

3. A lot of unnecessary information about the hotels, shops and catering points, and as a result, find the attraction becomes difficult.

4. Information, it is usually necessary to read that move not only inconvenient but also not safe.

Thus, the tourist tour guide should contain a story about sights, and need it to be in the form of a record.

Today's mobile application created for tablets PC and smartphones, it is an innovative tool to stimulate domestic tourism and investment promotion [1]. The main advantages of mobile applications are: simplifying communication between the brand and the user, the economic benefits and ease of using. Depending on the specifics of the company and current business priorities, mobile applications can be an effective marketing tool to attract new customers or convenient service to work with the existing customer base.

Interactive guides are able to find geolocation and constructing routes, integration with social networks, virtual gallery, use the application without a permanent network connection, interactive menus, including video, motion graphics, 3D, audio commentaries, pie pan [12]. It can be embedded in the application of marketing tools - stock surveys. Special counters will allow to conduct a detailed analysis of user interaction with the content. You can also enter information about the infrastructure of all types for people with disabilities [20].

It should be noted that the publication of the application, with the active support of the information, is immediately reflected on the sales results. For example, a round-stream in «Snejnaya derevnya» after the publication of the application has quadrupled. Significantly increased revenues in hotels and restaurants in Yaroslavl, after the application was first shown at an exhibition in China, then in London, and after the release of the Russian version. And the app «Meschersky Park» prefer large regions as a counterpart to create the guides with built-in monetization scheme.

The Russian market of audio guides for smartphones not very saturated yet. There are dozens of applications of different levels of quality, among which stand out favorably from the audio guides of TravelMe - beautiful, functional and intuitive to use. In each of the applications from TravelMe can find from six to ten destinations of the city's main attractions, the total duration of more than two hours, more than 50 colorful photos and GPS-map for better orientation in place. Nothing extra - everything is simple and very easy, just download the app on your phone, select Desirable route, including headphones and go for a walk at their own pace.

The growth of mobile applications market in Russia is one of the most significant among the world's major markets. The main trend that people are more interested in a quality product. Now for the success of the application alone is no longer enough of a good idea. The user always need comfortable and beautiful realization, otherwise the product will not be in demand simply and quickly take his place competitors.

Belgorod has rich historical and cultural heritage. On the territory of the regional center is full of monuments, monuments, open after famous Belgorod, divided into these beds, parks and squares. 
Belgorod is a city with a long history. Save for her contemporaries and successors is one of the tasks that confront a city government [11].

«Open air museum» is intended to inform residents about the major milestones of the history of Belgorod, do stay in the city fascinating. Recently, the city-museum added a monument to the first governor of the Belgorod Yuri Troubetzkoy, Drenyakiny generals next contact sculptures, small architectural forms. Mayor of the City Sergei Bozhenov believes that form and develop the citizens, to instil in them a love for their native places - also a problem of the urban environment.

Many citizens and guests celebrate the historic attraction of Belgorod thanks to the project «Open air museum». Some offer their suggestions on how to continue it.

Modern Belgorod is not only convenient for life, but also attractive city for tourists. Here soar into the sky dome of numerous temples, admiring its beauty. Over recent years, interesting sculptures, including a monument to Pushkin and Natalie, builders, St. Peter and Fevronia of Murom. The city opened the so-called thematic recreation areas for both adults and children - it is squares of friendship, love, and Yesenin Egorovsky [16].

Belgorod Literary Museum in the region first began providing audio tours using mobile applications. Innovation is designed for smartphones and tablet computers with operating systems iOS and Android.

\section{Discussion}

In our view, now tourism has not reached the proper level of development, to influence the economy of the Belgorod region. In the Belgorod region is actively developing rural tourism in the framework adopted in 2007 the regional program «Development of rural tourism in the territory of municipalities «Belgorod region», «Valuiki and Valuysky region» and «Graivoronsky region» in 2007 - 2010» and the program «Development of rural tourism in the Belgorod region in 2011 2013 years». The program brings together about one hundred mansions and town houses. Among them, guesthouses, agroindustrial and sightseeing estate, in some of which the current owners maintain lifestyle and traditions of old families [7]. Leader in the development of rural tourism is Graivoronovsky region. Along with the development of agro-tourism in the Belgorod region, a project on the creation of recreational areas in the municipalities. So, in Prokhorovskii region built four tourist complex: «Rysskaya ysad'ba», «Ribazkaya artel», «Sloboda kochevnikov» and park complex «Klychi» [17].

Showed the conducted researches that at this stage of development of excursion and museum activity changes in technologies of mobile excursion projects are also observed. To replace the projects based on traditional audioguides projects with interactive opportunities and/or with links to the sites of social networks gradually come.

In many excursion places where all mobile projects once were under construction on the basis of audioguides, the first mobile projects which can be carried to the category of the interactive more likely are now developed. It testifies to the growing desire of excursion places through mobile technologies to realize new types of projects.

In the technological aspect, isolated cases of failure sightseeing places of projects in which visitors to access the content of the tour is available for rent special equipment. Part of this substitution takes place on mobile applications for smartphones downloading visitors. But it seems that more often than not come to replace projects implemented on the basis of sites optimized for mobile access.

The museums and other expositions are more concentrated on mobile projects for constant expositions I collections, than on projects for temporary exhibitions. Possibly, it is connected with rather long life cycle of mobile projects.

Traditional audioexcursions form the main share of the existing projects today. However they become less popular with excursion places which else prepare the first mobile project.

The following trends:

- new projects seek for interactivity,

- excursion places create mobile projects directly on expositions, than projects outside expositions still more often. However, we will notice that this gap is reduced,

- noticeable growth of interest of excursion places in implementation of the mobile projects with links to the sites social networks is observed,

- the planned mobile projects in a smaller measure are focused on temporary exhibitions, in a bigger measure on constant collections.

One of the most interesting directions in the field of applications programming for iPhone, iPad and Android is a creation of the program of augmented reality which allows to look absolutely in a different way at that that surrounds us. The program allows to impose the additional information layers with graphics simulated on usual surrounding reality.

Within research the analysis of appeal of tourist resources of the Belgorod region taking into account hierarchy 
which assumes statement of a problem of research, definition of the purpose (in this case definition of the most attractive tourist objects of the chosen group), criteria of various levels and alternatives (the provided list of objects) was carried out.

\section{Findings}

At an assessment of degree of appeal of tourist objects of the Belgorod region, the chosen objects were grouped in the directions. The preference of alternatives is caused by their greatest popularity in the studied segment and existence of the exhibits reflecting the greatest importance and value as for inhabitants of the Belgorod region, and guests of the region.

In the course of research it was revealed that now social and economic conditions and resources of the Belgorod region favor to development and functioning in its territory of tourist and recreational branch. It is in many respects caused by an advantageous geographical position, preparation of qualified personnel for tourist branch, development of tourist infrastructure and reconstruction of establishments of rest, interest of the regional authorities in development of tourist sector of the market. So, optimum recreational opportunities on indicators of infrastructure potential are noted in the cities of Belgorod, Stary Oskol, Gubkin. These cities act as the backbone, multifunctional recreational and tourist centers and are located in a zone of the best transport availability.

Creation of a tourist mobile application is preceded by preliminary creation of the project which is realized by the developer, considering his features: analysis of an exposition; development of the suitable decision; creation of a product; control, introduction, advance.

Technical project of tourist mobile application should be based on the concept agreed with the city administration, and meet the following requirements: must include a functional structure; project design of mobile applications; should be formed requirements for the main and auxiliary pages of the application, to the logic of the transition between pages the user application. Necessary to provide effective integration with social services, the use of mailings to interested consumers with information corresponding to the media content contribute to the emergence of new customers interested possibility of easy use functional software.

The received results of an assessment of appeal of objects of tourism of the Belgorod region will be used further for preparation of content for mobile applications for the purpose of development of regional tourism in the Belgorod region, and also for the purpose of formation of the competitive tourist offer for increase of appeal of the region as object of internal and entrance tourism.

Modern mobile guides should combine interactivity, accessibility, information, and professional content. You must first determine the position of the user to find suitable objects on the map, to provide high-quality media content (audiovisual description of cultural objects; preparing tourist routes), and bind the tourists and guides in the field.

According to sociological research ARCSPO every fourth tourist is a potential user of mobile guides, the market of mobile guides is 8.91 million dollars. (at a cost of $\$ 0.99$ for product.) Thus, we can conclude that mobile apps are a tool for tourism development and attracting investment.

\section{Acknowledgments}

The study was performed in the framework of grants for scientific research on priority areas of socio-economic development of the Belgorod region «Increasing the attractiveness of tourist areas on the basis of introduction of multimedia and interactive content».

\section{References}

Mobile Phone Augmented Reality: Market Analysis and Forecast (2014). URL: http://www.gartner.com/hc/images/215650_001.gif Mobile and tourism (2015). URL:http://innospace.ru/mobile-i-turizm/

Pan B., Xiang Z., Law R., Fesenmaier D.R. (2011) The dynamics of search engine marketing for tourist destinations. Journal of Travel Research, 50(4). 2011. P. 365-377.

«Vi» analyzed the mobile market in Russia (2015). URL: http://www.cossa.ru/news/247/98331/

Vishnevskaya E.V., Klimova T.B., Dumacheva E.V., Bogomazova I.V. (2014) Current issues in the development of modern guide using GIS-technologies // Advances in Environmental Biology, 8 (13) August 2014, P. 305-308.

Xiang Z., Pan B., (2011). Travel queries on cities in the United States: Implications for search engine marketing for tourist destinations. Tourism Management, 32(1), 2011. P. 88-97.

Goz I.G. (2014) Problems of development of tourism in the Belgorod region, 2004 URL: http://belgorod.ru/tourism/Goz.htm 
Research «Global Augmented Reality (AR) Market Forecast by Product (HMD, HUD, Tablet PC, Smartphone) for Gaming, Automotive, Medical, Advertisement, Defense, E-learning \& GPS Applications («Market and Markets» company, November 2011). Open part of the report. URL: http://www.slideshare.net/it-park/ar-min-2012201.

Research «Mobile Augmented Reality Forecasts, Applications \& Oppor-tunity Appraisal 2009-2014» Juniper Research company, 2009. Open part of the report. http://www.juniperresearch.com/reports.php? id=197.

Klimova T.B., Vishnevskaya E.V. (2014) Mobile technologies in the development of tourist destinations // Scientific Review. №8. 2014, P. 666-669.

Kovalev Y.P. (2003) Tourist and recreational potential and the development of tourism sector in the region // Tourism, environment and sustainable development of the regions: proceedings of the international scientific-practical conference. Tver: Tver State University, 2003, P. 211-219.

Krasovskaya O.S. (2005) GIS in the system of spatial planning and management of the territory: a textbook for high schools. - M.: ArcReview, 2005. - $238 \mathrm{p}$.

Mobile applications for travelers are becoming increasingly popular (2015). URL: http://www.rg.ru/2014/06/24/prilozenija.html

Background of development of recreation and tourism in the Belgorod region (2007) / Koroleva I.S, Petin A.N. // Materials of the AllRussian scientific-practical conference «Strategy of development of tourism and recreation in the regions»: Makhachkala. 2007, P. 41-47.

The market for mobile applications in Russia and in the world (2015). URL:http://web.json.ru/poleznye_materialy/free_market_watches/ analytics/rynok_mobilnyh_prilozhenii_v_rossii___mire/

Ryapuhina V.N. (2007) Problems of development of the tourist potential of the Belgorod region / Ryapuhina V.N., Shevtsov S.N., Nikulina T.Y. 2007.

Socio-economic conditions and the organization of recreation in the Belgorod region (2008) / Petin A.N, Koroleva I.S. // Geography and Tourism: Sat. scientific. tr. Perm, 2008. Vol. 5. P. 101-107.

Top-10 best rated companies (2015) URL: http://www.ruward.ru/index-ruward/united-mobile-rating-2015/

Shmatchenko V.F. (1995) Application of information technology for the development of tourism in Russia // Proceedings of the Academy of Tourism. - St. Petersburg, 1995.

Yakovenko I.M. (2014) Possibilities of GIS in geographical research and regional management of recreational nature, 2000. URL: http: // dataplus.ru/tourism/Goz.htm. 